bioRxiv preprint doi: https://doi.org/10.1101/2020.12.09.417527; this version posted December 10, 2020. The copyright holder for this preprint (which was not certified by peer review) is the author/funder, who has granted bioRxiv a license to display the preprint in perpetuity. It is made available under aCC-BY-ND 4.0 International license.

\title{
CLEAN AND FOLDED: OPTIMIZED PRODUCTION OF HIGH QUALITY RECOMBINANT HUMAN INTERFERON- $\Lambda 1$
}

\author{
Aram Shaldzhyan ${ }^{a}$, Nikita Yolshin ${ }^{a}$, Yana Zabrodskaya ${ }^{a, b, c}$, Tatiana Kudlingd, \\ Alexey Lozhkov ${ }^{\mathrm{a}, \mathrm{b}}$, Marina Plotnikova ${ }^{\mathrm{a}}$, Edward Ramsay ${ }^{\mathrm{a}}$, Aleksandr Taraskin ${ }^{\mathrm{a}, \mathrm{b}}$, \\ Peter Nekrasov ${ }^{\mathrm{a}}$, Mikhail Grudinina ${ }^{\mathrm{a}}$ Andrey Vasina,
}

\section{Keywords}

Interferon-lambda;

immobilized metal ion affinity chromatography;

cation exchange chromatography;

refolding

\section{Corresponding author:}

\section{Dr. Yana A. Zabrodskaya}

Smorodintsev Research Institute of Influenza, Russian Ministry of Health, Department of Molecular Biology of Viruses

Address: 197376, Prof. Popov St. 15/17,

St. Petersburg, Russia

yana@zabrodskaya.net;

yana.zabrodskaya@influenza.spb.ru

\section{ABSTRACT}

Type III interferons exhibit antiviral activity against influenza viruses, coronaviruses, rotaviruses, and others. In addition, this type of interferon theoretically has therapeutic advantages, in comparison with type I interferons, due to its ability to activate a narrower group of genes in a relatively small group of target cells. Hence, it can elicit more targeted antiviral or immunomodulatory responses. Obtaining biologically-active interferon lambda (hIFN$\lambda_{1}$ ) is fraught with difficulties at the stage of expression in soluble form or, in the case of expression in the form of inclusion bodies, at the stage of refolding. In this work, hIFN- $\lambda_{1}$ was expressed in the form of inclusion bodies, and a simple, effective refolding method was developed. Efficient and scalable methods for chromatographic purification of recombinant hIFN- $\lambda_{1}$ were also developed. Highyield, high-purity product was obtained through optimization of several processes including: recombinant protein expression; metal affinity chromatography; cation exchange chromatography; and an intermediate protein refolding stage. The obtained protein was shown to have expected, specific biological activity in line with published effects: induction of MxA gene expression in A549 cells.

\section{INTRODUCTION}

Interferons play a critical role in the immune response by suppressing viral spread in the early stages of infection and form the first line of defense against viral infection in mammals [1,2]. According to amino acid sequence and type of receptor through which signal transmission is mediated, interferons are divided into three groups: types I, II, and III [1,3]. Type III interferons (lambda interferons, IFN- $\lambda$ ) are related to type I interferons (interferon- $\alpha$ and interferon$\beta$ ) and demonstrate a similar antiviral effect $[4,5]$. Type III interferons are promising therapeutic agents that can induce a more targeted antiviral or immunomodulatory response than other interferon types [6,7]. Such interferons primarily affect viruses that target cells of the respiratory tract, gastrointestinal tract, or liver [8]. Thus, type III interferons exhibit antiviral activity against a number of respiratory and gastrointestinal viruses: influenza virus; metapneumovirus; respiratory syncytial virus; coronavirus; and rotavirus [6]. Availability of a simple, effective method for producing type III interferons is a necessary prerequisite for further research of its potential as an antiviral or immunomodulatory agent. In previously published work, methods for production of recombinant $h I F N-\lambda_{1}$ in soluble form with the proteolytically cleaved S-tag [9], and in the form of inclusion bodies with 6His-tag $[5,10]$, have been proposed. In this work, we cloned and expressed recombinant human interferon- $\lambda_{1}\left(\mathrm{hIFN}-\lambda_{1}\right)$. Along with the 6 His-tag, inclusion body approach, we propose: a simple and effective refolding method; and an efficient, potentially-scalable chromatographic purification method. The hIFN- $\lambda_{1}$ produced features specific activity suitable for research and, potentially, future diagnostic or therapeutic application.

\footnotetext{
a Smorodintsev Research Institute of Influenza, Russian Ministry of Health, 15/17 Prof. Popov St., St. Petersburg, Russia 197376

b Peter the Great Saint Petersburg Polytechnic University, 29 Polytechnicheskaya St., Petersburg, Russia 194064

c Petersburg Nuclear Physics Institute named by B. P. Konstantinov of National Research Center "Kurchatov Institute", mkr. Orlova roshcha 1, Gatchina, Russia 188300

d Cancer Gene Therapy Group, Translational Immunology Research Program, University of Helsinki, Helsinki, Finland
} 
bioRxiv preprint doi: https://doi.org/10.1101/2020.12.09.417527; this version posted December $10,2020$. The copyright holder for this preprint (which was not certified by peer review) is the author/funder, who has granted bioRxiv a license to display the preprint in perpetuity. It is made available under aCC-BY-ND 4.0 International license.

\section{MATERIAL AND METHODS}

\subsection{Materials}

Reagents obtained from Sigma included: tris base; $\mathrm{Na}_{2} \mathrm{HPO}_{4}$; $\mathrm{NaCl}$; EDTA; PMSF; Tween 20; glycerol; acetonitrile; TFA; trehalose; L-arginine; sodium acetate; acetic acid; $\mathrm{HCl}$; and urea. HisTrap FF Crude and Source 15S 4.6/100 columns were obtained from GE Healthcare; BioScale Mini P6 cartridges and TGX anyKD precast SDS-PAGE gels were obtained from Bio-Rad. For endotoxin evaluation, the LAL Chromogenic Endpoint Assay (\#HIT302, Hycult Biotech) was used. For enzymatic hydrolyses, trypsin and chymotrypsin (Promega) were used. Matrices for MALDI-TOF mass spectrometry (HCCA) were manufactured by Bruker.

Lambda interferon levels were evaluated by human IL-29/IL-28B (IFN-lambda 1/3) DuoSet ELISA (DY1598B, R\&D Systems, USA). Biological activity experiments were performed using: the A549 cell line (ATCC, CCL-185); F12K media, fetal bovine serum, and DPBS manufactured by Gibco (USA); and 12-well plates from Thermo Scientific Nunc (USA). Total RNA isolation and realtime PCR were performed using: TRIZol reagent (Invitrogen, USA); M-MLV reverse transcriptase, MMLV Reaction Buffer, and ultrapure water (Promega, USA); BioMaster HS-qPCR (BioLabMix, Russia); and oligo(dT)16 primers (DNA-Synthesis, Russia).

\subsection{Plasmid construction}

In silico optimized sequence (https:/www.genscript.com/tools/gensmart-codon-optimization), encoding hIFN- $\lambda_{1}$ \#Q8IU54 [11], was synthesized by Evrogen and cloned into the pet302-NT-His plasmid. That vector contains a sequence encoding a polyhistidine tag at the $\mathrm{N}$ terminus of synthesized protein. The resultant construct (pet302-NT-His-hIFN- $\lambda_{1}$ ) was checked for errors by sequencing.

\subsection{Protein expression}

Escherichia coli cultures (BL-21 DE3) were transformed with pet302-NT-His-hIFN- $\lambda_{1}$ and seeded on Luria Bertani (LB) agar plates containing ampicillin $(100 \mu \mathrm{g} / \mathrm{ml})$. Individual colonies were picked and grown overnight in LB media
( $0.5 \%$ yeast extract, $1 \%$ Bacto tryptone, $1 \% \mathrm{NaCl}$ ) containing ampicillin. The overnight cultures were then used to inoculate fresh LB medium containing ampicillin $\left(\mathrm{OD}_{600}=0.1\right.$ at start of new incubation). Bacterial cultures were cultivated with agitation (orbital shaker) to an $\mathrm{OD}_{600}$ value of 0.7. To optimize cultivation conditions, protein expression was induced by various IPTG concentrations $(0.01,0.05,0.1 \mathrm{mM})$, and cultures were incubated further (orbital shaker, $32^{\circ} \mathrm{C}$ or $37^{\circ} \mathrm{C}, 3$ hours). Cultures were sonicated (MSE ultrasonic disintegrator) on ice ( 10 pulses, of 10 seconds each, in 30-second intervals), followed by centrifugation for 1 hour $\left(20,000 \mathrm{~g}\right.$ at $\left.+4^{\circ} \mathrm{C}\right)$. Supernatants and pellets were collected separately. Levels of hIFN$\lambda_{1}$ expression, and its presence in supernatants or pellets (inclusion bodies), were determined by polyacrylamide gel electrophoresis (SDS-PAGE).

\subsection{Protein purification and refolding}

Chromatographic purification was performed on a GE Healthcare AKTA pure $25 \mathrm{M}$ system. Primary purification of $\mathrm{hIFN}-\lambda_{1}$ was performed by immobilized metal affinity chromatography (IMAC) under denaturing conditions. Cells were precipitated by centrifugation for $10 \mathrm{~min}$ at 4,500 $\mathrm{g}\left({ }^{+} 4^{\circ} \mathrm{C}\right)$. Next, cell pellets ( $1 \mathrm{~g}$ wet weight) were resuspended in $30 \mathrm{ml}$ of denaturing buffer $(20 \mathrm{mM}$ sodium phosphate, $300 \mathrm{mM}$ sodium chloride, $8 \mathrm{M}$ urea, 20 mM imidazole, pH 7.8, 1 mM PMSF); suspensions were sonicated (MSE ultrasonic disintegrator) using 10 pulses (30 seconds each, at 2 minute intervals) on ice. Lysate was clarified by centrifugation for 20 minutes at $13,000 \mathrm{~g}\left({ }^{+} 10^{\circ} \mathrm{C}\right)$.

A $1 \mathrm{~mL}$ HisTrap FF Crude column was equilibrated with $5 \mathrm{ml}$ of binding buffer ( $30 \mathrm{mM}$ sodium phosphate, $300 \mathrm{mM}$ sodium chloride, $8 \mathrm{M}$ urea, 20 $\mathrm{mM}$ imidazole, $\mathrm{pH} 7.8$ ) at a flow rate $0.5 \mathrm{ml} / \mathrm{min}$. Clarified lysate was loaded onto the column (at a flow rate of $0.2 \mathrm{ml} / \mathrm{min}$ ), followed by washing with $20 \mathrm{ml}$ of binding buffer. The target protein was eluted with $5 \mathrm{ml}$ of elution buffer ( $30 \mathrm{mM}$ sodium phosphate, $300 \mathrm{mM}$ sodium chloride, $8 \mathrm{M}$ urea, $500 \mathrm{mM}$ imidazole, $\mathrm{pH}$ 7.8) at a flow rate of $0.2 \mathrm{ml} / \mathrm{min}$. Eluate was monitored by optical density (280 nm wavelength), and fractions of the target protein with an $\mathrm{OD}_{280}$ greater than $300 \mathrm{mAU}$ 
were collected. EDTA $(0.5 \mathrm{M})$ was added to target protein fractions to a final concentration of $5 \mathrm{mM}$. Protein concentration was determined by chromatogram integration using Unicorn 6 software, assuming: the absorbance of a $0.1 \% \mathrm{hIFN}-\lambda_{1}$ solution at $280 \mathrm{~nm}$ to be 0.85 per $\mathrm{cm}$ of optical path (calculated based on primary protein sequence using the ProtParam service).

Protein refolding was performed by the dilution method. Chilled refolding solution was placed on a magnetic stirrer, and a solution of denatured protein $(2 \mathrm{mg} / \mathrm{ml})$ was added dropwise to a final concentration of $0.1 \mathrm{mg} / \mathrm{ml}$. The resulting solution was stirred for 10 minutes and then incubated for 24 hours at ${ }^{+} 4^{\circ} \mathrm{C}$. The resulting refolded protein solution was filtered through a PES syringe filter $(0.45 \mu \mathrm{m}$ pore size).

Final purification was performed by cation exchange chromatography. A SOURCE ${ }^{\mathrm{TM}} 15 \mathrm{~S}$ $4.6 / 100$ column was equilibrated with $8 \mathrm{ml}$ of start buffer (20 mM Tris hydrochloride, $2 \mathrm{mM}$ EDTA, $\mathrm{pH} 7.5$ ) at a flow rate of $2 \mathrm{ml} / \mathrm{min}$. Next, refolded and filtered protein solution was loaded onto the column, followed by column washing with $10 \mathrm{ml}$ of start buffer $(2 \mathrm{ml} / \mathrm{min})$. Target protein was eluted with a linear salt gradient $(0$ to $1 \mathrm{M} \mathrm{NaCl})$ in start buffer at a flow rate of $2 \mathrm{ml} / \mathrm{min}$ for 15 minutes. Eluate was monitored by optical density at $280 \mathrm{~nm}$; fractions $(0.5 \mathrm{ml})$ featuring $\mathrm{OD}_{280}$ values above $25 \mathrm{mAU}$ were collected. Fractions were analyzed by polyacrylamide gel electrophoresis. Fractions containing target protein with minimal impurities were combined. The Bio-Scale Mini P6 Desalting Cartridge (Bio-Rad) was used to transfer into phosphate buffered saline ( $\mathrm{pH}$ 7.2). Protein concentration was determined by the Lowry method.

\subsection{Product analysis}

\subsubsection{SDS-PAGE}

Purified protein was analyzed by SDS-PAGE using the Laemmli method under reducing conditions [12]. Electrophoresis materials used (BioRad) included: 'Any kD TGX' precast gels; Kaleidoscope Plus Protein Ladder; PowerPac Basic DC power source; and Mini Protean Tetra cell. Gels were stained with a Coomassie solution as de- scribed [13]. Gels were visualized using the ChemiDoc MP gel documentation system and analyzed using Bio-Rad Image Lab Software.

\subsubsection{Enzyme-linked immunosorbent assay}

ELISA was carried out using commercial reagents. Levels of hIFN- $\lambda_{1}$ were evaluated by human IL-29/IL-28B (IFN-lambda 1/3) DuoSet ELISA (DY1598B, R\&D Systems, USA), according to manufacturer's instructions. A different commercial kit, Mouse IL-28 A/B (IFN-lambda 2/3) DuoSet ELISA (DY1789B, R\&D Systems), was used to assess cross-reactivity.

\subsubsection{MALDI-TOF}

The amino acid sequence of recombinant $6 \mathrm{xHis}-\mathrm{hINF}-\lambda_{1}$ protein was confirmed using MALDI-TOF mass spectrometry. Following PAGE, fragments were excised from gel and washed twice for dye removal $\left(30 \mathrm{mM} \mathrm{NH}_{4} \mathrm{HCO}_{3}\right.$ in $40 \%$ acetonitrile). Gel fragments were next dehydrated with $100 \%$ acetonitrile, dried in air, and subjected to enzymatic digestion by trypsin or chymotrypsin. Trypsin $(20 \mathrm{ug} / \mathrm{ml}$ in $50 \mathrm{mM}$ $\mathrm{NH}_{4} \mathrm{HCO}_{3}$ ) was added to gel, and incubation was performed for 2 hours at $60^{\circ} \mathrm{C}$. Incubations with chymotrypsin $(20 \mathrm{ug} / \mathrm{ml}$ in $100 \mathrm{mM}$ Tris- $\mathrm{HCl}, 1$ $\mathrm{mM} \mathrm{CaCl}_{2}, \mathrm{pH}$ 8.0) were performed for 18 hours at $25^{\circ} \mathrm{C}$. In both cases, reactions were stopped with $1 \%$ TFA in $10 \%$ acetonitrile. Peptides after enzymatic digestion were mixed with HCCA matrix, put onto the metal target, and their mass spectra recorded in positive ion registration reflective mode using the UltrafleXtreme MALDI-TOF mass spectrometer (Bruker). Spectra were processed in flexAnalysis software (Bruker). Protein identification was performed in BioTools (Bruker) using MASCOT (http://www.matrixscience.com/). It should be noted that: recombinant protein amino acid sequence (Fig. 1b) was added to the local database; during the identification process, the two databases (local and SwissProt, https://www.uniprot.org/) were used simultaneously. Mass tolerance was established as $20 \mathrm{ppm}$; oxidation of methionine was indicated as a variable modification. Identification was considered reliable based on spectrum score and threshold $(\mathrm{p}<0.05)$. 


\subsection{Biological activity}

Type I and type III interferons induce the expression of ISGs (interferon stimulated genes) through their heterodimeric receptors. One of the key antiviral ISGs is MxA [3]. Unlike most ISGs, the $\mathrm{Mx}$ genes are not characterized by constitutive expression; their expression is specifically caused by the action of type I and III IFNs. This makes MxA an excellent marker of activation of an IFNdependent response [14]. Thus, biologically active hIFN- $\lambda_{1}$ should induce MxA expression. To determine changes in MxA mRNA level, real-time qPCR analysis was performed following sample preparation (RNA isolation, reverse transcription)

\subsubsection{Cell treatment}

A549 (carcinomatous alveolar basal epithelial cell line) cells were used. Cells were cultured using: F12K media with $1 \%$ GlutaMax and $10 \%$ fetal bovine serum; and 12 -well plates $\left(5 \times 10^{5}\right.$ cells/well). Monolayers were washed with DPBS and treated with $10 \mathrm{ng} / \mathrm{ml} \mathrm{hIFN}-\lambda_{1}$. After $10 \mathrm{~h}$ or $24 \mathrm{~h}$ of incubation $\left(37^{\circ} \mathrm{C}, 5 \% \mathrm{CO}_{2}\right.$, humidification), hIFN- $\lambda_{1}$ was removed. Cell monolayers were washed again with DPBS. The treated cell cultures and non-treated controls were harvested.

\subsubsection{RNA isolation}

Total RNA was isolated from A549 cells using TRIZol reagent according to manufacturer's instructions. RNA concentration and general integrity were measured using a NanoDrop ND-1000 spectrophotometer (NanoDrop Technologies,

\section{RESULTS AND DISCUSSION}

\subsection{Plasmid construction}

An in silico optimized (http://genomes.urv.es/OPTIMIZER/obtimized.php) sequence encoding hIFN- $\lambda_{1}$ was synthesized and cloned into pet302 NT-His plasmid by Evrogen. The resultant plasmid was verified by sequencing and found to contain no errors. The pet302 NTHis vector contains sequence encoding a 6 histidine tag at the $\mathrm{N}$-terminus of recombinant protein. The resultant recombinant protein amino acid sequence, encoded by the construct (plasmid pet302 + hIFN- $\lambda_{1}$ ), is shown in Figure $1 \mathrm{~b}$.
USA).

\subsubsection{Reverse transcription reaction}

Following RNA extraction, samples were reverse transcribed using M-MLV reverse transcriptase (M-MLV RT) as described [15]. A mixture of $2 \mu \mathrm{g}$ total RNA and $1 \mu \mathrm{g}$ oligo(dT) ${ }_{16}$ primers, adjusted with ultrapure water to a final volume of 12 $\mu \mathrm{l}$, was incubated at $70^{\circ} \mathrm{C}$ for $5 \mathrm{~min}$. Tubes were immediately cooled on ice, and a mix was then added containing: $5 \mu \mathrm{l} 5 \mathrm{x}$ MMLV Reaction Buffer; $1.5 \mu \mathrm{l} 5 \mathrm{mM}$ dNTPs; $1 \mu \mathrm{l}$ M-MLV RT; and $5.5 \mu \mathrm{l}$ ultrapure water. Complementary DNA synthesis was carried out at $42^{\circ} \mathrm{C}$ for $60 \mathrm{~min}$. Enzyme (MMLV RT) was inactivated by heating $\left(65^{\circ} \mathrm{C}, 5 \mathrm{~min}\right)$. Products were stored at $20^{\circ} \mathrm{C}$.

\subsubsection{Real-time $q P C R$}

Real-time qPCR assays were performed using the CFX96 Real-Time PCR System (Bio-Rad). Reaction mixtures contained: $12.5 \mu \mathrm{l}$ of $2 \mathrm{x}$ BioMaster HS-qPCR; $0.5 \mu \mathrm{l}(0.6 \mu \mathrm{M})$ of each primer and probe; $2 \mu \mathrm{l}$ of first-strand cDNA; and $9 \mu \mathrm{l}$ of ultrapure water. Amplification was performed using the following conditions: an activation step $\left(95^{\circ} \mathrm{C}\right.$, $5 \mathrm{~min}$ ); and 40 cycles of amplification $\left(95^{\circ} \mathrm{C}\right.$ for 15 sec; $60^{\circ} \mathrm{C}$ for $60 \mathrm{sec}$ ). Fluorescence detection was performed in each cycle at the $60^{\circ} \mathrm{C}$ step. The comparative cycle threshold method $(\Delta \Delta C T)$ was used to quantitate $\mathrm{MxA}$ expression. Results were normalized to GAPDH endogenous reference expression levels. At least three biological replicates were used for each data point. Statistical analyses were performed using GraphPad Prism 6.0.

\subsection{Protein expression}

Upon IPTG induction, a BL-21 DE3 cell culture transformed with the pet302-NT-His-hIFN- $\lambda_{1}$ plasmid showed expression of a protein with a molecular weight of about $21 \mathrm{kDa}$. The theoretical molecular weight of the protein was $21.3 \mathrm{kDa}$. In the experiment, the concentration of inducer and the incubation temperature were varied. The incubation time with the inducer was 3 hours. Each sample was fractionated (Figure 2a).

Under the conditions tested, the target protein was expressed in the form of inclusion bodies. According to the literature $[5,10,16]$, this is a 
bioRxiv preprint doi: https://doi.org/10.1101/2020.12.09.417527; this version posted December 10, 2020. The copyright holder for this preprint (which was not certified by peer review) is the author/funder, who has granted bioRxiv a license to display the preprint in perpetuity. It is made available under aCC-BY-ND 4.0 International license.

(a)

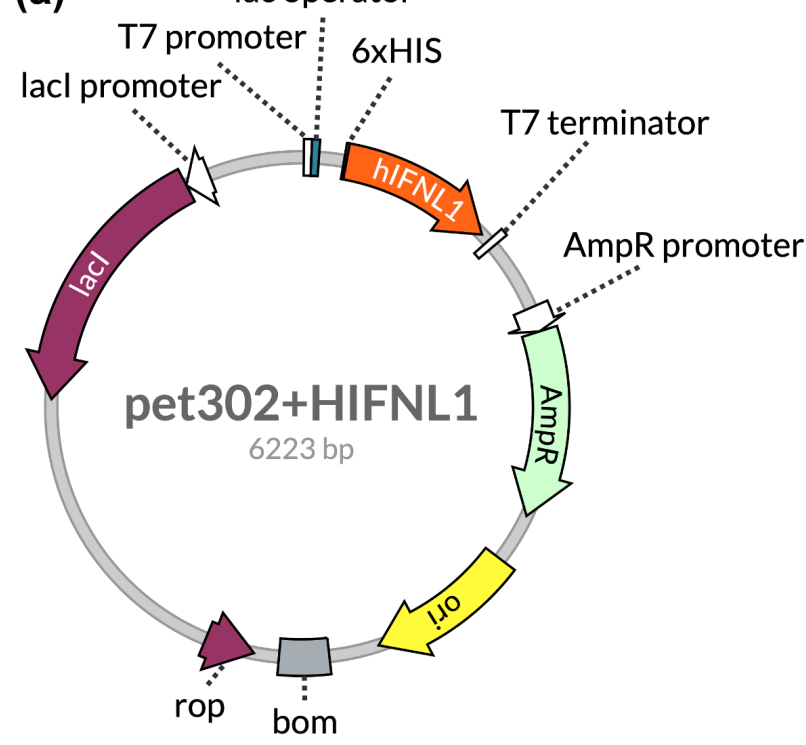

(b)

1 MHHHHHHVNS GPVPTSKPTT TGKGCHIGRF KSLSPQELAS

41 FKKARDALEE SLKLKNWSCS SPVFPGNWDL RLLQVRERPV

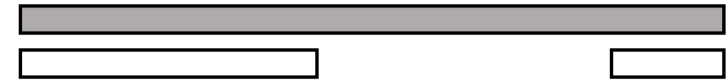

81 ALEAELALTL KVLEAAAGPA LEDVLDQPLH TLHHILSQLQ

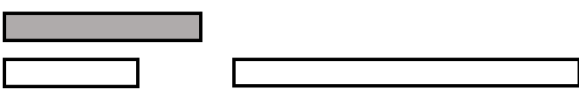

121 ACIQPQPTAG PRPRGRLHHW LHRLQEAPKK ESAGCLEASV

161 TFNLFRLLTR DLKYVADGNL CLRTSTHPES T

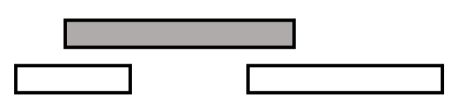

Figure 1. (a) Specifics of the pet302+ hIFN- $\lambda_{1}$ expression plasmid. (b) Amino acid sequence of the 6xHis$\mathrm{hIFN}-\lambda_{1}$ recombinant protein. Additional aa residues between the polystydine tag and hIFN- $\lambda_{1}$ are indicated in italics. Sequence regions identified using mass spectrometry (section 3.4.1) are highlighted: black bars and white bars indicate enzymatic digestion with trypsin or chymotrypsin, respectively.

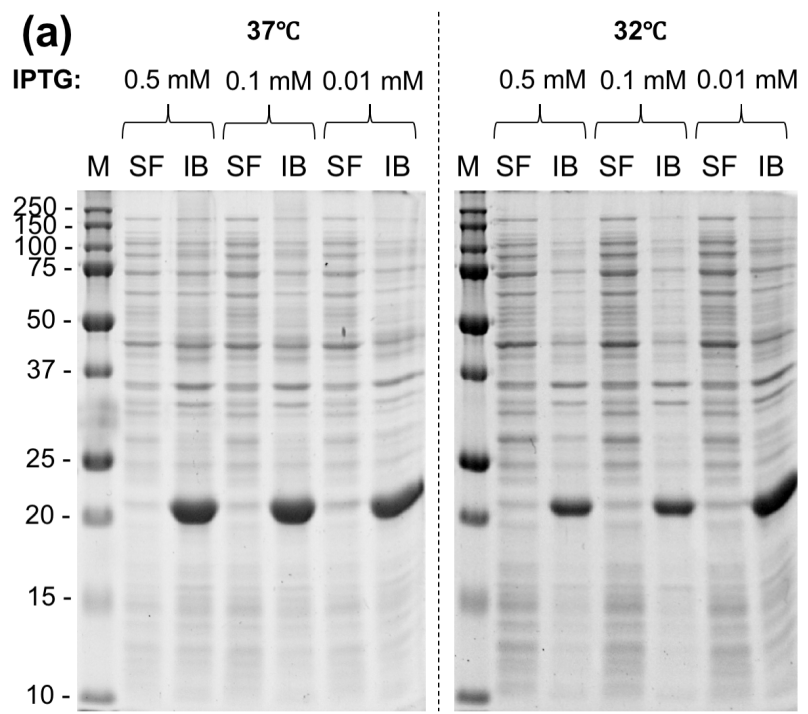

(b)

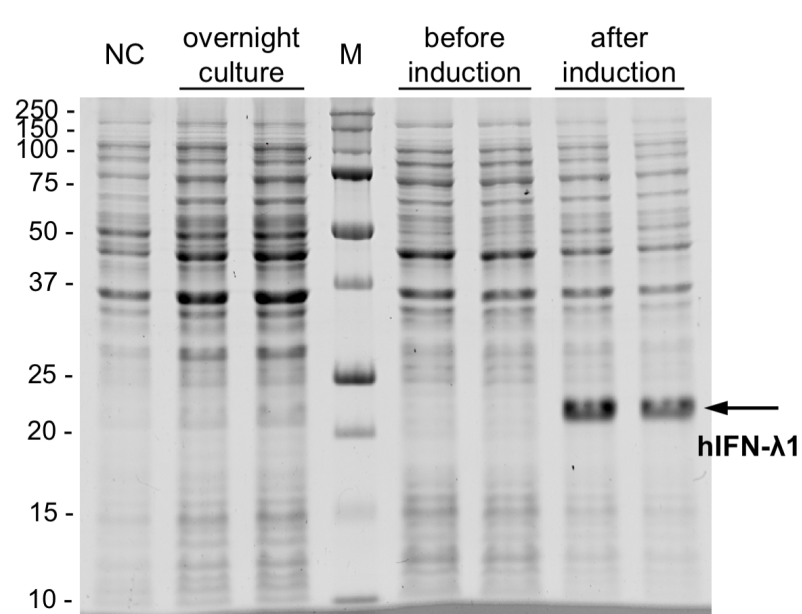

Figure 2. Electrophoresis of lysate fractions from the hIFN- $\lambda_{1}$ producing strain ( $E$. Coli BL-21). (a) Induction testing. The $\mathrm{x}$-axes show IPTG concentration used for induction. Incubation temperatures are shown (left $37^{\circ} \mathrm{C}$, right $32^{\circ} \mathrm{C}$ ). SF - soluble fraction; IB - inclusion bodies. (b) Protein production. 'Overnight culture' - overnight culture, subcultured for production; 'Before induction' - cell lysate before addition of inducer; and 'After induction' - cell lysate, 3 hours after addition of inducer. NC - negative control ( $E$. Coli BL-21 without plasmid).

common occurrence with production of recombinant interferons in $E$. Coli. It should be noted that the $\mathrm{hIFN}-\lambda_{1}$ gene was also cloned into the pet22b+vector, at the MscI and XhoI sites, in order to create a fusion protein not only with a histidine tag at the C-terminus, but also with pelB sequence at the $\mathrm{N}$-terminus. The pelB sequence encodes a signal peptide, potentially contributing to periplasmic protein localization. However, even in the presence of the signal peptide, recombinant protein was localized in inclusion bodies (data not shown).

Since cultivation conditions and the presence of pelB sequence did not increase the amount of soluble protein, production of hIFN- $\lambda_{1}$ was carried out using: pet302 NT-His plasmid; LB medium with ampicillin $(100 \mu \mathrm{g} / \mathrm{ml}) ; 37^{\circ} \mathrm{C}$ incubation; and platform agitation $(250 \mathrm{rpm})$. When conditions were met (culture $\mathrm{OD}_{600}=0.7$ arbitrary units), IPTG was added (0.05 mM final concentration), 
and cultivation with induction was continued for 3 more hours (Fig. 2b).

\subsection{Protein purification and refolding}

Primary protein purification was carried out by metal affinity chromatography under denaturing conditions. This purification method, with on-column refolding of hIFN- $\lambda_{1}$ described earlier [10], showed low yield of refolded protein (less then 5 $\mathrm{mg}$ of correctly-folded protein per liter of culture). Therefore, it was decided to perform the first purification step under denaturing conditions, followed by refolding of the partially purified protein. Ni-Sepharose 6FF resin (prepacked HisTrap FF Crude columns) was chosen because of its high dynamic binding capacity (about $35 \mathrm{mg}$ of hIFN$\lambda_{1}$ per $1 \mathrm{ml}$ of sorbent) and the possibility of further scale-up. The chromatogram of the first purification step is shown in Figure 3a.

Two refolding buffers with different $\mathrm{pH}$ (tris$\mathrm{HCl}, \mathrm{pH}$ 7.5; sodium acetate, $\mathrm{pH}$ 5.5), with and without refolding additives, were selected for screening. Denatured recombinant protein samples (at a concentration of $2 \mathrm{mg} / \mathrm{ml}$ ) were added to pre-cooled refolding buffer (to final concentration of $100 \mu \mathrm{g} / \mathrm{ml}$ ) and mixed by pipetting, followed by incubation for 24 hours at $+4^{\circ} \mathrm{C}$. Precipitated protein was removed by centrifugation for 1 hour at

20,000 g. Supernatants were collected and dialyzed against phosphate buffered saline for 24 hours, followed by filtration through a PES syringe filter $(0.2 \mu \mathrm{m}$ pore size). Protein concentrations were determined by the Lowry method. For estimation of relative 'soluble protein yield' of refolding variations, $100 \mu \mathrm{g} / \mathrm{ml}$ was designated as $100 \%$. The results of the experiment are shown in Table 1.

Table 1. Soluble protein yield in various refolding buffers.

$\begin{array}{ll}\text { Refolding Buffer } & \text { Soluble } \\ & \text { Protein } \\ & \text { Yield, \% }\end{array}$

(A) $20 \mathrm{mM}$ tris- $\mathrm{HCl}, \mathrm{pH} 7.5 \quad 42$

(B) $20 \mathrm{mM}$ tris-HCl, $1 \mathrm{M} \mathrm{L}$-arginine, $\mathrm{pH} 7.5$

(C) $20 \mathrm{mM}$ tris- $\mathrm{HCl}, 20 \%$ glycerol, $\mathrm{pH} 7.5$

(D) $20 \mathrm{mM}$ tris- $\mathrm{HCl}, 5 \%$ trehalose, $\mathrm{pH} 7.5$

$20 \mathrm{mM}$ tris- $\mathrm{HCl}, 0.1 \%$ Tween-20, $\mathrm{pH} 7.5$

(F) $10 \mathrm{mM}$ sodium acetate, $\mathrm{pH} 5.5$

(G) $10 \mathrm{mM}$ sodium acetate, $5 \%$ trehalose, $\mathrm{pH} 5.5$

(b)
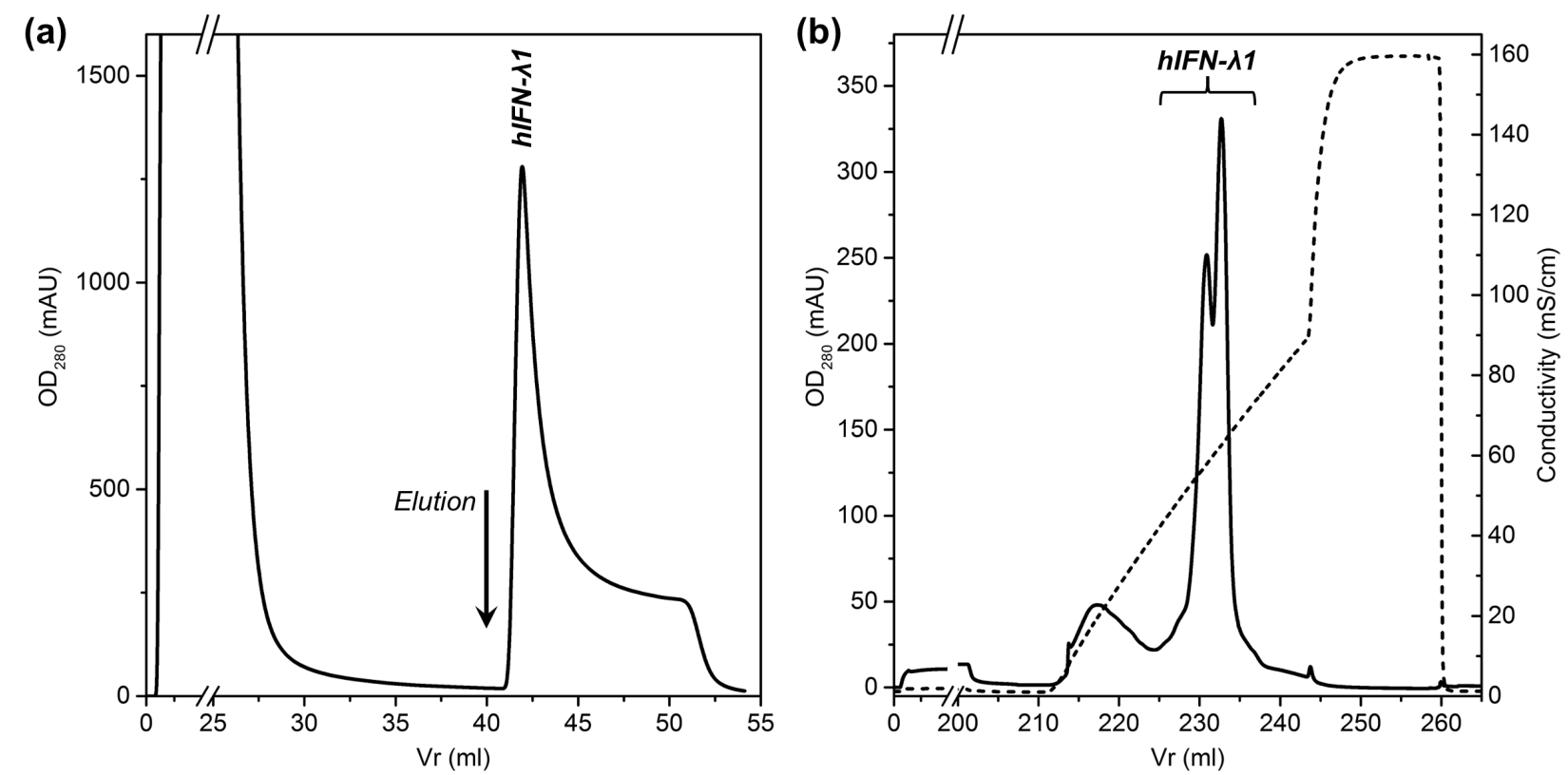

Figure 3. (a) Primary purification of recombinant hIFN- $\lambda_{1}$ by IMAC. Absorbance at $280 \mathrm{~nm}$ is shown in blue; elution buffer concentration is shown in pink. (b) Final purification of recombinant hIFN- $\lambda_{1}$ by cation exchange chromatography. Blue indicates absorption at $280 \mathrm{~nm}$; red indicates conductivity of the solution. 
The highest yields of recombinant hIFN- $\lambda_{1}$ in soluble form were seen with two specific refolding buffers: Buffer C (80\%); and Buffer E (89\%). The proposed refolding method provides a significantly higher yield, takes less time, and is more economical in comparison with the stepwise dialysis method proposed [5] for IFN- $\lambda_{3}$, another type III interferon. Conductivity of the protein solution after refolding was about $5 \mathrm{mS} / \mathrm{cm}$; therefore, it does not interfere with subsequent ion-exchange chromatography. There is thus no need for dialysis or diafiltration of the refolded protein solution. It is possible to proceed directly to the final purification step.

The isoelectric point of the hIFN- $\lambda_{1}$ recombinant protein was 9.08 according to the ProtParam Tool [17]. Thus, hIFN- $\lambda_{1}$ in refolding solution is positively charged, so cation exchange chromatography was chosen as a final purification step. With comparison of different cation exchange resins, the best results (maximum protein yield, minimal impurities) were noted (data not shown) with resins featuring particle size of $15 \mu \mathrm{m}$ or less, such as Source 15S (GE Healthcare) and ENrich S (BioRad). Source 15S was selected because of higher flow rates and availability for purchase in bulk (for potential process scale-up later). The chromatogram of the final protein purification step is shown in Figure $3 \mathrm{~b}$. The target protein eluted in the conductivity range from 45 to $65 \mathrm{mS} / \mathrm{cm}$. It should be noted that hIFN- $\lambda_{1}$ elutes as a double peak, which may indicate the presence of two different conformational variants.

The method makes it possible to obtain up to 70 mg of recombinant hIFN- $\lambda_{1}$ from $1 \mathrm{~L}$ of cell culture ( $5.2 \mathrm{~g}$ wet weight). Expression in the form of inclusion bodies protects the protein from proteolysis during cultivation. Simple and effective refolding provides a high yield of native-form protein with proven biological activity.

\subsection{Product analysis}

\subsubsection{SDS-PAGE and MALDI-TOF}

The purity of the recombinant protein was analyzed by SDS-PAGE. Figure 4 shows all steps of target protein purification.

The presence of a band with an electrophoretic mobility of about $21 \mathrm{kDa}$ (indicated by an arrow) indicates selective isolation of the protein from the

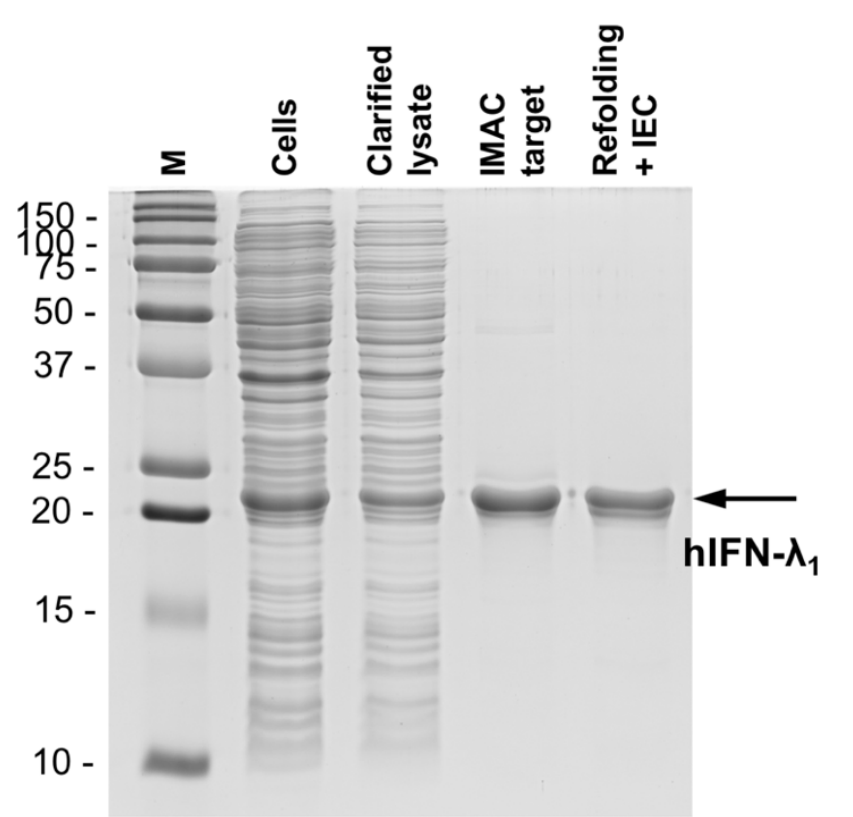

Figure 4. PAGE of $6 \mathrm{His}-\mathrm{hIFN}-\lambda_{1}$-containing samples at various stages. Key: $\mathrm{M}-$ marker (Precision Plus mol. weight standard); 'Cells' - whole cell suspension; 'IMAC target' - target peak from metal-affinity column; 'Refolding + IEC' - material after refolding followed by cation exchange chromatography. Coomassie staining.

protein mixture present in the cell culture.

Confirmation of recombinant protein amino acid sequence was carried out using MALDI-TOF mass spectrometry after enzymatic hydrolysis of 'protein in gel' with trypsin. In the area marked with an arrow (Fig. 4), the $6 x$ His-hIFN- $\lambda_{1}$ recombinant protein was reliably identified (Score/threshold was 156/76, sequence coverage $70 \%$ ). Additional hydrolysis with chymotrypsin extends the sequence coverage to $85 \%$. Protein sequences found in mass spectra are highlighted in Figure 1b. Thus, the obtained protein was reliably identified as human interferon lambda-1 (6xHishIFN- $\left.\lambda_{1}\right)$.

\subsubsection{ELISA}

Binding of the recombinant protein with antihIFN $\lambda_{1}$ monoclonal antibodies was shown by sandwich ELISA. The commercial 'Human IL29/IL-28B (IFN-lambda 1/3) DuoSet ELISA' kit (DY1598B, R\&D Systems) was used (Fig. 5).

For each concentration, the average optical absorbance $\left(\mathrm{OD}_{450}-\mathrm{OD}_{655}\right)$ is indicated in relative units. Concentrations of hIFN- $\lambda_{1}$ were determined by the Lowry method. These results show that a constant $+4^{\circ} \mathrm{C}$ temperature is the preferred storage 


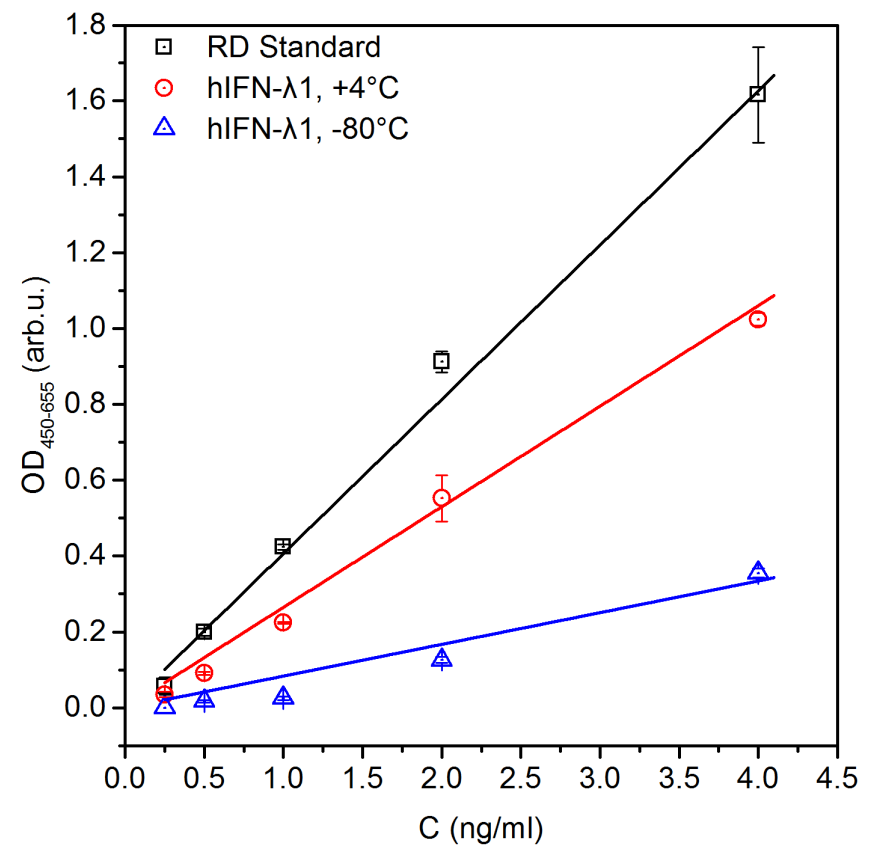

Figure 5. Comparison of ELISA signal from recombinant $\mathrm{hIFN}-\lambda_{1}$ stored in different conditions. In addition to the two storage conditions $\left(4^{\circ} \mathrm{C}\right.$ and $\left.-80^{\circ} \mathrm{C}\right)$, a commercial standard is shown from the 'Human IL-29/IL28B kit (IFN-lambda 1/3) DuoSet' ELISA kit (DY1598B, R\&D Systems).

condition for recombinant hIFN- $\lambda_{1}$ protein, not $80^{\circ} \mathrm{C}$ followed by thawing. Increasing the stability of the protein product is a priority goal for further improvement of this method. Ideally, this would minimize changes associated with one or more 'freeze-thaw' cycles.

\subsection{Confirmation of biological activity}

\subsubsection{Limulus amebocyte lysate testing}

In order to exclude the possibility of stimulation of A549 cells by bacterial lipopolysaccharides, the endotoxin level was determined by LAL test. The results show that recombinant $\mathrm{hIFN}-\lambda_{1}$ solution contains endotoxin at a concentration of about $25 \mathrm{EU} / \mathrm{ml}$, which corresponds to no more than $5 \mathrm{ng} / \mathrm{ml}$ of endotoxin [18]. The concentration of the analyzed sample was $620 \mu \mathrm{g} / \mathrm{ml}$. Consequently, there was less than $0.05 \mathrm{EU}$ endotoxin per $\mu \mathrm{g}$ of protein, which is in line with commercial analogues on the market [19]. Thus, endotoxins present in the solution should not significantly affect the immune response of cells. Moreover, it has been shown that lipopolysaccharides do not induce the production of either IFN $-\alpha / \beta$ or IFN- $\lambda$ in respiratory epithelial cells $[14,20]$. The A549 cells used here are also a respiratory epithelial line, and lipopolysaccharide-induced MxA expression is not expected

\subsubsection{Real-time PCR}

The biological activity of hIFN- $\lambda_{1}$ was shown by RT-PCR. Increased MxA expression was shown in A549 cells treated for 10 hours with hIFN- $\lambda_{1}(10$ $\mathrm{ng} / \mathrm{ml}$ ) compared to control cells (Fig. 6). The level of MxA expression increased by more than 20fold. Since $\mathrm{MxA}$ is an interferon-stimulated gene, increased expression can be considered reliable evidence of the biological activity of the obtained hIFN- $\lambda_{1}$ [14].

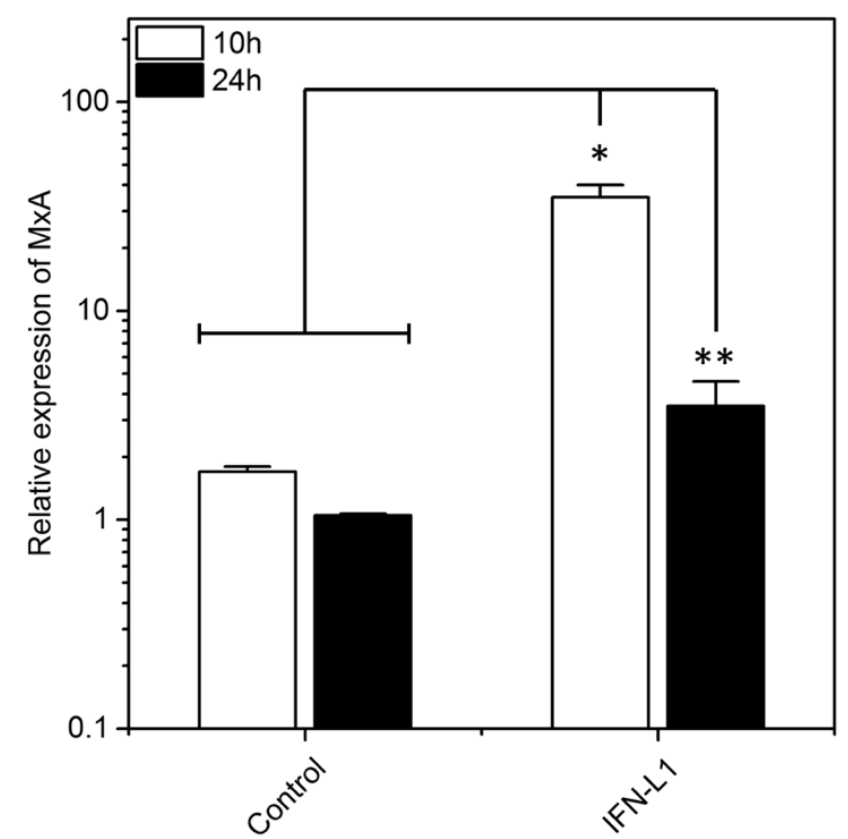

Figure 6. Change in $\mathrm{MxA}$ expression in A549 cells treated with hIFN- $\lambda_{1}(10 \mathrm{ng} / \mathrm{ml})$ for 10 or 24 hours during incubation. The $\mathrm{y}$-axis shows relative MxA expression; the $\mathrm{x}$-axis shows cell treatment conditions. The differences in MxA-2 mRNA expression between the control group at $10 \mathrm{~h}$ and the control group at $24 \mathrm{~h}$ were insignificant ( $\mathrm{p}=0.3333$ ). T-test was performed using the nonparametric Mann-Whitney test. ${ }^{*} \mathrm{p}$-value $=0.0286 ;{ }^{* *} \mathrm{p}$-value $=0.0159$.

AUTHOR CONTRIBUTIONS were as follows: A.S. - methodology, data collection, data analysis, writing of manuscript; A.L., N.Y., M.P. — data collection, data analysis, writing of manuscript; T.K., A.T., P.N. — data collection, data analysis; Y.Z. data collection, data analysis, writing of manuscript, visualization; E.R. - writing, review and editing of manuscript; M.G., A.V. - resources, supervision.

ACKNOWLEDGMENTS. This work was supported by a Russian State Assignment for fundamental research (0784-2020-0023). 


\section{CONCLUSION}

In this work, we developed an efficient and potentially-scalable method for refolding and purification of recombinant human hIFN- $\lambda_{1}$. The purified protein was confirmed to feature the expected biological activity. The developed method pro-

\section{REFERENCES}

[1] M.J. Killip, E. Fodor, R.E. Randall, Influenza virus activation of the interferon system, Virus Res. 209 (2015) 11-22. doi:10.1016/j.virusres.2015.02.003.

[2] M.D.R. Baños-Lara, L. Harvey, A. Mendoza, D. Simms, V.N. Chouljenko, N. Wakamatsu, K.G. Kousoulas, A. Guerrero-Plata, Impact and Regulation of Lambda Interferon Response in Human Metapneumovirus Infection, J. Virol. 89 (2015) 730742. doi:10.1128/JVI.02897-14.

[3] R.E. Randall, S. Goodbourn, Interferons and viruses: an interplay between induction, signalling, antiviral responses and virus countermeasures, J. Gen. Virol. 89 (2008) 1-47. doi:10.1099/vir.0.83391-0.

[4] M.R. Thompson, J.J. Kaminski, E.A. Kurt-Jones, K.A. Fitzgerald, Pattern Recognition Receptors and the Innate Immune Response to Viral Infection, Viruses. 3 (2011) 920-940. doi:10.3390/v3060920.

[5] C. Dellgren, H.H. Gad, O.J. Hamming, J. Melchjorsen, R. Hartmann, Human interferon- $\lambda 3$ is a potent member of the type III interferon family, Genes Immun. $\quad 10$ (2009) 125-131. doi:10.1038/gene.2008.87.

[6] P. Hermant, T. Michiels, Interferon- $\lambda$ in the Context of Viral Infections: Production, Response and Therapeutic Implications, J. Innate Immun. 6 (2014) 563-574. doi:10.1159/000360084.

[7] S. Davidson, S. Crotta, T.M. McCabe, A. Wack, Pathogenic potential of interferon $\alpha \beta$ in acute influenza infection, Nat. Commun. 5 (2014) 3864. doi:10.1038/ncomms4864.

[8] H.M. Lazear, T.J. Nice, M.S. Diamond, Interferon- $\lambda$ : Immune Functions at Barrier Surfaces and Beyond, Immunity. $\quad 43 \quad$ (2015) 15-28. doi:10.1016/j.immuni.2015.07.001.

[9] M. Li, S. He, Purification and characterization of recombinant human interleukin-29 expressed in Escherichia coli, J. Biotechnol. 122 (2006) 334-340. doi:10.1016/j.jbiotec.2005.11.019.

[10] M. Li, D. Huang, On-column refolding purification and characterization of recombinant human interferon $-\lambda 1$ produced in Escherichia coli, Protein Expr. Purif. 53 (2007) 119-123. doi:10.1016/j.pep.2006.11.011.

[11] IFNL1 - Interferon lambda-1 precursor - Homo sapiens (Human) - IFNL1 gene \& protein, (n.d.). https://www.uniprot.org/uniprot/Q8IU54 (accessed vides a high yield of protein with low impurity content, such as lipopolysaccharide. It is therefore potentially suitable for isolation of type III interferons not only for research and diagnostic applications, but also for therapeutic use.

December 2, 2020).

[12] U.K. Laemmli, Cleavage of Structural Proteins during the Assembly of the Head of Bacteriophage T4, Nature. 227 (1970) 680-685. doi:10.1038/227680a0.

[13] A.A. Shaldzhyan, Y.A. Zabrodskaya, I.L. Baranovskaya, M. V Sergeeva, A.N. Gorshkov, I.I. Savin, S.M. Shishlyannikov, E.S. Ramsay, A. V Protasov, A.P. Kukhareva, V. V Egorov, Old Dog, New Tricks: Influenza A Virus NS1 and In Vitro Fibrillogenesis, BioRxiv. (2020) 188300. doi:10.1101/2020.08.17.254060.

[14] O. Haller, P. Staeheli, M. Schwemmle, G. Kochs, Mx GTPases: dynamin-like antiviral machines of innate immunity, Trends Microbiol. 23 (2015) 154-163. doi:10.1016/j.tim.2014.12.003.

[15] M.A. Plotnikova, S.A. Klotchenko, A. V. Vasin, Development of a multiplex quantitative PCR assay for the analysis of human cytokine gene expression in influenza A virus-infected cells, J. Immunol. Methods. $\quad 430 \quad$ (2016) 51-55. doi:10.1016/j.jim.2016.01.005.

[16] Z. Zou, D. Yu, M. Zhao, L. Dong, L. Zhao, M. Zou, H. Liu, M. Zhang, H. Sun, Design and evaluation of novel interferon lambda analogs with enhanced antiviral activity and improved drug attributes, Drug $\begin{array}{lllll}\text { Des. Devel. Ther. } 10 & \text { (2016) } 163 .\end{array}$ doi:10.2147/DDDT.S91455.

[17] ExPASy - ProtParam tool, (n.d.). https://web.expasy.org/protparam/ (accessed November 1, 2020).

[18] Cell Culture FAQs: Bacterial Endotoxin Contamination | Sigma-Aldrich, (n.d.). https://www.sigmaaldrich.com/technicaldocuments/articles/biology/what-is-endotoxin.html (accessed November 28, 2020).

[19] Recombinant Human Interferon lambda-3(IFNL3) (Active) - Cusabio, (n.d.). https://www.cusabio.com/Interleukin/RecombinantHuman-Interferon-lambda-3-IFNL3-12923581.html (accessed November 28, 2020).

[20] I. Ioannidis, F. Ye, B. McNally, M. Willette, E. Flano, Toll-Like Receptor Expression and Induction of Type I and Type III Interferons in Primary Airway Epithelial Cells, J. Virol. 87 (2013) 3261-3270. doi:10.1128/jvi.01956-12. 